Address for correspondence:

Dr Tom Moultrie

Andrew W Mellon Foundation Postdoctoral Fellow in Demography

Centre for Actuarial Research

University of Cape Town

Private Bag, Rondebosch

7700 SOUTH AFRICA

Telephone: $\quad+27(0) 216502475$

Fax: $\quad+27(0) 216897580$

Email: $\quad$ tmoultri@,commerce.uct.ac.za

\title{
The South African fertility decline: Evidence from two censuses and a Demographic and Health Survey
}

(Short title: Fertility decline in South Africa)

Tom A. Moultrie

Centre for Actuarial Research, University of Cape Town

Ian M. Timæus

Centre for Population Studies, London School of Hygiene \& Tropical Medicine 


\section{Abstract}

Inadequate data and apartheid policies mean that, until recently, most demographers have not had the opportunity to investigate the level of, and trend in, South African fertility. The 1996 South Africa Census and the 1998 Demographic and Health Survey (DHS) provide the first widely available and nationally representative demographic data on South Africa since 1970. Using these data, this paper describes the South African fertility decline from 1955 to 1996. Having identified and adjusted for several errors in the 1996 Census data, it argues that total fertility at that time was 3.2 children per woman nationally, and 3.5 children per woman for African South Africans. These levels are lower than in any other sub-Saharan African country. We also show that fertility in South Africa has been falling since the 1960s. Thus, fertility transition predates the establishment of a family planning programme in the country in 1974.

KEYWORDS:

AFRICA, SOUTHERN-AFRICA, SOUTH-AFRICA, FERTILITY, FERTILITY-RATE, DEMOGRAPHIC-TRANSITION, APARTHEID 


\section{Introduction}

The collection of the 1996 South Africa Census and 1998 South Africa Demographic and Health Survey (DHS) data has opened up many avenues for substantive research into recent demographic trends in South Africa that were previously restricted and circumscribed through lack of data. This paper presents a detailed analysis of the changing level of and trends in fertility in South Africa over the period from 1955 to 1996, and pays particular attention to the determination of fertility levels in the country using the most recent data available: the 1996 South Africa Census and the 1998 South Africa Demographic and Health Survey. We begin with a description of the demographic data collected in the apartheid era, suggesting that a range of internal and external factors contributed to the very thin literature on South African fertility. We then proceed to describe and evaluate the data used to arrive at a reliable estimate of South African fertility in the closing years of the twentieth century. Finally, we apply reverse-survival methods to the 1996 and 1970 censuses in an effort to verify the trends in fertility reported by Apartheid-era demographers.

Recent fertility rates are estimated both by province and by race, while past trends in fertility are estimated for all South Africans and for African South African women separately. The unfortunate legacy of apartheid and segregationist policies is such that important demographic outcomes (especially mortality, but also some of the proximate determinants of fertility) differ in crucial ways according to population group. The term 'African' is currently preferred in South Africa to 'Black', which tends to signify non-'White' to those who opposed apartheid. The commonly-used South African term 'Coloured' refers to people of mixed race. Our use of apartheid-era classifications of the population implies neither that we condone that system nor that believe that our species can be divided into discrete biologically-defined races.

\section{The intersection of demography and politics under apartheid}


Until recently, South African fertility has been under-examined for two reasons. First, South African demography was hampered for most of the last century by inadequate census and vital registration data relating to the African population. Even according to three of the most senior apartheid-era demographers, 'the census coverage of the African population in the 1904, 1911 and 1921 censuses is viewed as being poor in all respects, the 1936 and 1970 censuses as reasonably good, and those of 1946, 1951, 1960 and 1980 again as less good' (Mostert, van Tonder and Hofmeyr 1987, p.3). The granting of 'independence' to four 'homeland' states between 1976 and 1981 further exacerbated the difficulties of census collection in the country. The three then-'independent' states conducted their own censuses in 1980, while five separate censuses were conducted in 1985.

Questions on African fertility (the number of births in the last year and deaths of children under the age of 1 in the last year) were introduced in the 1960 Census, and included again in the 1970 Census. A further question on children ever-borne was introduced in the 1980 Census. While 'usable' age-specific fertility rates were derived from the 1960 data, the results from the 1970 Census 'could not have given a true representation of reality', and those from the 1980 Census were so bad as to be 'completely and utterly unusable' (Mostert, van Tonder and Hofmeyr 1987, pp.4-5). Thus, since 1960, the calculation of age-specific fertility rates directly from census data has been impossible. Most of these data are no longer retained in archival format either: the 1970 census data files that are now made available do not even contain the fertility data.

In addition, South Africa's international isolation meant that it was excluded from the scope of the World Fertility Survey in the 1970s and the first rounds of the Demographic and Health Surveys (DHS). Investigations into African fertility were undertaken periodically in the 1970s and 1980s by the Human Sciences Research Council (HSRC), the government's official social science research body (Lötter and van Tonder 1976; van Wyk 1980; Mostert and Lötter 1990). In particular, the HSRC conducted a 'DHS' survey in 1987-89 using many of the same 
questions as the USAID-funded series of DHS surveys run with technical assistance from Macro International. However, the results of this and earlier HSRC inquiries were not disseminated widely and, initially, the 1987-89 DHS data were not made available to independent researchers.

The most frequently cited estimates of past African and South African fertility (cited by Caldwell and Caldwell (1993) and Chimere-Dan (1993a) amongst others) are those from Mostert, van Tonder and Hofmeyr (1987). However, these estimates need to be treated with circumspection, since they appear to have been determined in part by what the original authors deemed to be reasonable estimates of fertility. Table 1 shows estimates of South African fertility derived from HSRC and census data by HSRC demographers for the period 1945-95.

\section{Table 1 about here}

The second reason for the limited research on South African demography is that apartheid policies and practices led to the explicit politicisation of South African demography and demographic statistics. As Mostert, van Tonder and Hofmeyr (1988) have noted, the Afrikaans for demography (prior to the widespread use of the anglicism demografie) was politiese wiskunde 'political arithmetic'. While the term is not unique to South Africa, it is indicative of the reflexive relationship that existed between population and polity in the country. Mostert, van Tonder and Hofmeyr continue: 'The political arena in South Africa is, to a large extent, dominated by the 'arithmetic' of the local population structure, while political decisions have, over the years, exerted a great influence on population trends... In the discussion of demographic trends in South Africa, 'political arithmetic' in this country will of necessity occupy a prominent place' (1988, p.59). To put it baldly, Whites' fears of being numerically 'swamped' by Africans and the consequent perceived need to limit African fertility appear frequently in the rhetoric of Grand Apartheid. The threat of the subsumption of the White population, for example, led in 1967 to a cabinet minister, MC Botha, encouraging White South Africans to increase their fertility through tax relief and other benefits, and 'have a baby for Botha'. Earlier, in 1962, Prime Minister 
Verwoerd had articulated strongly the need for the independence of the Transkei [a region in what is now the Eastern Cape province, and the first of the 'homelands' to be granted 'independence' by the South African government], since a failure to do so 'would inexorably lead to Bantu domination. Because in the long run numbers must tell' (Verwoerd 1978 (1962), p.179). This last phrase is a direct quote from a paper written in 1950 by one of South Africa's most eminent demographers, Jan Sadie: 'In South Africa the outstanding problem, dominating all others, is the relative numbers of the different races constituting the Union's population, and their differential rates of growth. For in the long run, numbers must count' (Sadie 1950).

The sensitivity of demographic information in the Apartheid era not only meant that data collected on behalf of the South African government by the HSRC were not made generally available to researchers. In addition, the reports based on these surveys and studies were usually published only in Afrikaans, thereby further restricting the reports' accessibility to outsiders. Further, demography was absent from the teaching programmes of the English-medium universities due, in part, to the ideologically tainted nature of the discipline. Thus, research on the population emerging from these institutions tended to focus not on South African demography per se but on sociological and anthropological contextualisations of demographic processes (Preston-Whyte 1988; van der Vliet 1991; Preston-Whyte 1994).

Two other factors also served to the limit demographic research on South Africa. First, the impact of apartheid policies and racial capitalism does mean that the demography of South Africa is distinctive, with the consequence that the country has often been ignored in general discussions of the demography of sub-Saharan Africa. Second, South Africa was often omitted from international statistical series (such as those published by the UN and World Bank). This meant that data for South Africa were difficult to come by outside the country. Hence, they were often ignored by non-specialists.

All these factors, together with the boycott of South Africa by foreign academics that commenced in earnest in the 1980s, have ensured that the demography of South Africa has 
remained a terra incognita on the international map for much longer than that of any other Southern African country. Few demographers outside of the HSRC wrote on South African fertility until the early 1990s, and those that did had to make do with unverifiable published statistics. Their research tended to be derivative, insofar as they were not able to manipulate data themselves, and they focused instead on presenting syntheses, summaries and alternative interpretations of what published data were available. Examples of this literature include Lucas (1992), Caldwell and Caldwell (1993) and Chimere-Dan (1993b; 1993a; 1994). However, this state of affairs could, and did, it is argued here, lead to erroneous interpretations of South African fertility and the pace of the South African fertility decline.

In their 1993 article, Caldwell and Caldwell (1993) identify an apparent anomaly in South African fertility. They contrast the high level of African fertility with the extent and scope of the South African government's implementation of an 'Asian-type' family planning programme and the level of socio-economic development in the country and propose three explanations of the anomaly. Their first suggestion is that widespread community and political resistance existed to the government's family planning programme. As Kaufman (1996) has shown, however, while political resistance to the programme did exist, this resistance did not translate into a large-scale rejection by African women of government-sponsored contraception. The Caldwells' second explanation is that fertility control was 'pointless', since the social stratification of South African society made social mobility impossible. This does not square with economic histories of South Africa. Both Beinart (1994) and Lipton (1985) discuss the social changes that occurred in South African society, and the South African labour market particularly, between 1970 and 1990. These authors argue that, while social mobility was indeed difficult and obstructed, it was not impossible. More importantly, while this period was characterised by political repression, it also saw the gradual freeing up of the South African social order, as economic growth undid racist job-reservation policies and the government lost the political will to enforce restrictions on African urbanisation. The Caldwells' third argument, that there are 'profound cultural and social 
differences' in South Africa, resulting in a 'refusal' by Africans to limit their fertility is shown to be wrong by more recent data. This paper argues that these data reveal that South African fertility has been falling gradually for the best part of half a century, to a level that is low by developing country standards.

The political transition in the 1990s created the scope for non-governmental agencies to collect new demographic data and allowed demographers access to previously restricted data sets. The 1993 Living Standards and Development Study (SALDRU 1994), organised with the assistance of the World Bank, was the first large-scale survey conducted independently of the South African government and its agencies. While that study's focus is primarily on economics and poverty, it did collect data relating to fertility and mortality. In doing so, it provided researchers with independent means of evaluating the level and context of South African fertility. Fuller and Liang (1999) use the study to explore the relationships between socio-economic variables (especially education) and teenage pregnancy, while Mencarini (1999) uses the same data to estimate the level and correlates of fertility in South Africa.

Kaufman's doctoral research $(1996 ; 1998 ; 2000)$ marked an important milestone in the analysis of South African demography. She was among the first non-South Africans to gain access to HSRC data, and used the 1987-9 DHS-type survey to investigate the political context of reproductive control in South Africa. In so doing, she integrated demographic and political theory to give a more nuanced interpretation of the dynamics and political context of contraceptive usage during the South African fertility transition.

In recent years, the government's statistical agency, Statistics South Africa, has become more willing to publish or otherwise share the analyses underlying its demographic estimates. This has contributed to the debate on the level of fertility in South Africa. A summary of published estimates of total fertility in South Africa using data collected since 1993 is shown in Table 2. Two reports (Udjo 1997, 1998) analysing South African fertility using the 1995 October Household Survey (OHS) and the 1996 Census have been issued by Statistics South Africa and 
the first independent assessments of the current level of fertility in the country using the 1996 Census data have emerged (see, for example, Dorrington, Nannan and Bradshaw (1999) and Dorrington (1999)).

\section{Table 2 about here}

A further contribution to the study of the South African fertility transition has come from Sibanda and Zuberi (1999). They use a variant of the reverse-survival technique (the 'own-child' method) to assess the trend in South African fertility from 1981 to 1996 using the 1996 Census data. Although their methodology and assumptions have been criticised as being inappropriate to the South African context (Dorrington, Nannan and Bradshaw (1999)), and their results may be biased upwards due to their inadvertent linking of children to their grandmothers, the rates they derive nevertheless add to the extremely limited body of research on South African fertility.

Table 2 reveals wide variations in estimated levels of South African fertility. The primary objective of this paper then is to derive more robust estimates of the trend in South African fertility over the last few decades, using multiple data sources. We describe and analyse the trends in South African fertility between 1955 and 1996. In doing so, the paper provides a comprehensive account of the South African fertility decline over this period, and provides the most robust estimates of current levels of fertility in South Africa yet published using the 1996 Census.

\section{Data sources and quality}

The two main sources of data used are the 10 per cent public-use sample from the 1996 South Africa Census, and the 1998 South Africa Demographic and Health Survey (DHS). This section of the paper describes the sampling methodologies employed in the collection of the census and DHS data, and also the 1970 Census data, which are used to estimate fertility prior to this date. A Technical Report prepared by the authors for the South African Medical Research Council 
(Moultrie and Timæus 2002) describes in greater detail the background characteristics of women (all South Africans and Africans separately) of reproductive age in both data sets, and investigates the data for African women in greater detail to highlight discrepancies between the DHS and the 1996 Census. This section of the paper also details the adjustments to the 1996 South Africa Census data that are required to produce accurate estimates of recent fertility in the country.

\section{South Africa Census}

The 1996 South Africa Census was the first conducted in a post-apartheid South Africa, and was carried out on behalf of the South African government by the Central Statistical Service (now Statistics South Africa). The official census date was the night of 9-10 October 1996, but fieldwork was conducted over a three-week period from 10-31 October.

A post-enumeration survey in November 1996, together with detailed matching of records between the census and the PES, indicated that the undercount in the census was 10.7 per cent (Statistics South Africa 1998a), and varied by province (from 8.7 per cent in the Western Cape to 15.6 per cent in the Northern Cape). According to Statistics South Africa, infants and young adult men were particularly prone to under-enumeration, while Africans and Coloureds were less likely than Whites and Indians/Asians to have been enumerated. Statistics South Africa suggest that this pattern of underenumeration reflects different levels of urbanisation, and difficulties in achieving comprehensive coverage in rural areas (Statistics South Africa 1998a, p.20-21).

Statistics South Africa has made a ten per cent sample of the data available (for a fee) to researchers and included a weighting variable, designed to correct for the undercount as well as for the fact that the sample provided comprises one tenth of those enumerated. The data provided are based on a systematic sample of households, stratified by province and District Council. The individual-level data file includes all members of selected households, as well as a ten per cent systematic sample of people in 'special institutions' (old age homes, prisons, schools 
etc.) and hostels. Full details of the methods employed to derive the household sample are given in the documentation provided with the data (Statistics South Africa 1998b).

The raw data were checked and adjusted for double counting, as well as other errors, and cleaned and validated before their release. However, the algorithms employed to do this have not been published, making it impossible to assess the extent of imputation or modification of the data between its raw and final forms or to arrive at an independent judgement of whether any bias could have been introduced by this cleaning.

\section{South Africa DHS}

The 1998 South Africa Demographic and Health Survey (DHS) was co-ordinated by the Medical Research Council of South Africa (MRC) on behalf of the South African Department of Health. Technical assistance was provided by Macro International. The aim of the DHS was to collect detailed data on demographic and health variables within the country to assist policy making in the health sector (Department of Health 2002a).

The South Africa DHS employed a two-stage sample using the 1996 Census Enumeration Areas as a sampling frame with sample numbers of households derived in proportion to the number in the 1996 Census. The sample design is not self-weighting at a national level and sample weights are provided with the DHS data file to adjust the responses collected to be representative of the underlying sample frame (Department of Health 2002a).

A comparison of the background data from the 1996 census and the DHS is shown in Table 3.

\section{Table 3 about here}

\section{South Africa Census}

The results of the 1970 South Africa Census are used to derive estimates of South African fertility for the period 1955 to 1970 . These data were obtained on CD-Rom from Statistics South 
Africa and comprise the full population of Whites, Coloureds and Asians and a five per cent sample of Africans. Proportionally, the sample of Africans reflects that enumerated. However, weights are not available to adjust for any undercount of the population enumerated in 1970, or to reflect any differentials or biases in the census coverage. Likewise, no post-enumeration survey data are available for this census with which to form an opinion on the extent of the undercount.

The quality of the 1970 Census data for Africans is not nearly as good as it is in the 1996 Census. Strong digit-preference exists in the reporting of ages. Whipple's Index of digit preference for ages ending 0 or 5 is 140 for men aged 18 to 52, and 153 for women of the same ages. According to a United Nations scale, these values classify the reliability of the age data as 'rough' (Newell 1988). In addition, noticeable troughs exist in the reported population at age 1 for both sexes, as well as a dearth of male infants. Despite these deficiencies, the 1970 Census data provide the best demographic data for the South African population prior to the 1987-9 South Africa 'DHS', and allow us to derive estimates of South African fertility for earlier dates than is possible using only the 1996 Census and 1998 DHS data.

The 1996 Census and 1998 DHS data are not directly comparable. First, the DHS was conducted approximately 18 months after the census. With declining fertility (and rising mortality due to the HIV/AIDS epidemic), this may matter. Fertility measures from the DHS based on reported fertility in the three years before the interview, however, are centred on more-or-less the census date.

A particular advantage of the census data is that the large size of the ten per cent sample produces reasonable distributions of the South African population, even when the data are subjected to a high degree of disaggregation. The much smaller DHS sample usually does not permit analysis of fertility (or, indeed, any other demographic outcome) by more than a few characteristics at a time. 
A substantial number of corrections were required to make the 1996 Census fertility data usable. These are outlined in this section. Detailed descriptions of both the methods and the rationale behind these corrections have been published in the Technical Report (Moultrie and Timæus 2002).

The 1996 South Africa Census asked two questions from which fertility trends and levels can be assessed. The first question is 'How many children, if any, has the woman ever given birth to?' The second is 'How many children (live births), if any, has she given birth to in the last twelve months?' Responses to the first of these questions were not obtained for a significant proportion of women of childbearing age. Moreover, it seems that many respondents did not fully understand the second question, or that their responses were recorded inaccurately. The unadjusted census data cannot provide robust estimates of fertility and a series of corrections were made to them.

The first of these corrections uses the El-Badry correction (El-Badry 1961) to adjust for the fact that many of the women of childbearing age who did not respond to questions on the number of children ever borne are evidently childless. Furthermore, while the conventional formulation of the El-Badry correction applies to the reported numbers of children ever borne, the approach has also been used to adjust the data on women's reported births in the 12 months prior to the census, since women who have never given birth cannot have had a birth in the preceding 12 months.

A second correction makes allowance for the fact that women's reports of children ever borne in the census would appear to include a number of stillbirths. Comparisons of the DHS and census data on the children ever borne that have died and are still living (by age of mother) reveal higher numbers of dead children at all ages in the census, while the numbers of living children reported are very similar. Initially though, as many dead children were reported in the DHS as in the census. However, a detailed probe in the DHS asking whether dead infants had shown any signs of life revealed that about one quarter of them were in fact stillbirths, rather 
than live born children who subsequently died. Therefore an adjustment was made to the census data by fitting polynomial curves to the reported numbers of dead children by age of mother in both DHS and census, and differencing the (smooth) curves to estimate the number of stillbirths reported as dead live births in the census.

Further problems exist with the question on current fertility in the census. A significant proportion of enumerators or respondents seems not to have appreciated the distinction between this question and that on children ever-borne and recorded the same answer (i.e. children ever borne) to them both. Consequently, large numbers of women report three or more births in the 12 months preceding the census. This error has severe implications for the calculation of agespecific fertility rates and total fertility from the census data. Older women tend to have had more children, and hence age-specific fertility rates calculated without adjusting for this error are particularly exaggerated at the older age groups. A series of adjustments that restrict the number of births in the 12 months before the census to fewer than three were required to compensate for this error. Finally, a Relational Gompertz model was fitted to the estimates to adjust the shape of the fertility distribution - i.e. by fitting to the reported recent fertility data only, and not using the model to estimate the level of fertility (Zaba 1981).

The various adjustments made to the current fertility data eliminate about half the births that were reported as having occurred in the 12 months before the census, resulting in very low estimated fertility rates. It is clear, once one adjusts for problems with the coding and misinterpretation of the question listed already, that not all births that actually occurred in the 12 months before the census were reported. Thus, the final estimates of current fertility in South Africa made from the census data were derived using a variant of Brass' $\mathrm{P} / \mathrm{F}$ method, which estimates the current level of fertility from the lifetime fertility of women at the average age of childbearing (United Nations 1993; Feeney 1998).

The magnitude of the adjustments made suggest that the current fertility data in the census are of poor quality, largely as a result of enumerator error. It is imperative that any analysis of the 
1996 South Africa Census fertility data adjusts for the deficiencies outlined. Failure to do so will seriously distort estimates of current South African fertility. By contrast, the 1998 DHS data are of relatively good quality. However, while they are unaffected by the problems just outlined, problems were encountered during the fieldwork in at least one province (the Western Cape) and the DHS sample as a whole describes a better educated and more urbanised population than that enumerated in the 1996 Census (see Table 3). In addition, some evidence exists that rural women aged 40-44 in the DHS tended to understate their age (Moultrie and Timæus 2002).

\section{Estimates of recent fertility in South Africa}

This section compares the levels of lifetime and current fertility as estimated from the adjusted 1996 Census data and the 1998 South Africa Demographic and Health Survey (DHS). It presents data on mean children ever borne and estimates of fertility by population group. From these we derive estimates of national fertility. We then proceed to investigate past trends in South African fertility by means of reverse-survival techniques.

Table 4 shows the estimated mean children ever borne (CEB) by women, after the corrections made to the census data outlined in the previous section, by population group and age group in the 1996 South Africa Census and the 1998 South Africa DHS.

\section{Table 4 about here}

The estimated mean lifetime fertility from the adjusted census results and the DHS are shown in Figure 1. For African and Coloured women the estimates from the census and the DHS correspond extremely well. For White and Asian/Indian women, the data sources agree less well. This is no doubt partially a function of the small samples of women in these two groups in the DHS. The estimates of African women's lifetime fertility flatten out between ages 35 and 44 in the DHS. This further supports our earlier contention that rural African women in the 40-44 age group tended to understate their ages in the DHS. 


\section{Figure 1 about here}

\section{Estimates of current fertility: age-specific fertility rates by population group}

The estimated age-specific fertility rates arising from the census and the DHS are shown in Table 5. The effect of the adjustments made to the census data is not apparent if one only looks at total fertility. In contrast, the age distribution of fertility in the adjusted and unadjusted estimates obtained from the census is radically different. The estimates of Asian/Indian (and, to a lesser extent, White) fertility from the DHS are based on too small a sample to be reliable. DHS data for these two groups of women are shown for completeness' sake, and for comparison with the estimates drawn from the census data, although by themselves they are of little value in interpreting fertility levels.

\section{Table 5 about here}

The adjusted level of total fertility estimated from the census data is somewhat higher than that indicated by the DHS data, particularly for African women. This probably reflects the slightly more urban and educated profile of women interviewed in the DHS relative to that shown by the census data. This fact, together with our detailed evaluation of the current fertility data from the census, the much larger sample sizes involved, and our worries about the accuracy of the DHS data on the Western Cape, lead us to view the estimates arising from the census as being probably more representative of national fertility than those from the DHS.

The standardised fertility distributions (i.e. the age pattern of fertility if the TFR is 1) differ markedly by population group, with the distributions for African and Coloured women being relatively flat and those for Asians/Indians and Whites being far more concentrated around the mode (see Figure 2). The standardised distributions of fertility for African women are almost identical in the DHS and the adjusted census results. Minor differences exist for the 40-44 age group, as one would expect if the misstatement of age by rural women in this age group occurs in 
the DHS. The flatness of the fertility distribution at younger ages (and the high rate of fertility among adolescents) for African women is similar to the pattern identified in rural Limpopo province by Garenne, Tollman and Kahn (2000). They argue that it results from the combination of two components of similar magnitude: high premarital fertility among women aged 15 to 25 , together with a more usual distribution by age of marital fertility.

The shape of the fertility distribution among Coloured women differs quite substantially between the two data sets. This is probably accounted for by the difficulties experienced by DHS fieldworkers in adequately surveying the population of the Western Cape, where the majority of the Coloured population live. The fertility schedule for Indian/Asian women also differs between the DHS and the census. Although the mode of the DHS fertility distribution seems to be too low, this probably reflects the small sample size. The fertility schedule for White women has the same shape in both DHS and census - the higher peak in the 25-29 age group in the DHS simply reflects the fact that no White women over the age of 40 reported births in the three years before the survey.

\section{Figure 2 about here}

\section{National age-specific fertility rates}

Two approaches could be adopted for the calculation of national South African age-specific fertility rates. The first would be to use the national data set (i.e. not disaggregated by population group) from the census, and apply adjustments to it of the type applied here to the data on each of the individual population groups. The second approach is to weight the age- and population group-specific estimates just presented to give an estimated national schedule of fertility rates. The second approach seems preferable. Large differences exist between the fertility schedules for the four population groups presented in Table 5, in terms of both their level and their shape. Moreover, not all the adjustments we make to the data on African women are applicable to the data on minority population groups (for example, neither the correction in respect of stillbirths 
nor smoothing using the Relational Gompertz model seemed necessary for the data on Whites and Indians/Asians).

These points are not relevant to the DHS data, since neither the adjustment in respect of stillbirths, nor the Relational Gompertz model was applied. For the census, however, we estimate fertility for the country by combining rates for the four population groups weighting by the racial distribution of women in each age group. The final estimates of the national age-specific fertility rates are shown in Table 6. As with the estimated levels of fertility among African South African women, the estimates produced by the census data are somewhat higher than those indicated by the DHS. As already mentioned, the DHS sample was insufficient to produce reliable estimates of either White or Indian/Asian fertility (and in both cases, the census results produces higher estimates). The effect of the putative over-representation of educated, urban African women in the DHS, and the higher estimates of fertility among White and Indian/Asian women in the census lead us to place greater store by the national estimates of fertility produced using the census data.

\section{Table 6 about here}

\section{Provincial fertility estimates}

Past apartheid policies on urbanisation, and the creation of the so-called 'homelands' have created wide provincial disparities in health, education and socio-economic markers, as well as the racial composition of the population of each province. These differentials translate into widely disparate levels of fertility across the country. Provincial estimates of fertility using the adjusted census data and the DHS are shown in Table 7 . Unlike the national estimates, the provincial estimates are not calculated from a weighted average of estimated fertility for each population group in the province, as the number of observations in the DHS data (required to make the correction in respect of inclusion of stillbirths) preclude analysis by population and province simultaneously. 
While in all cases the level of fertility shown by the adjusted census data is lower than that shown by the DHS, there is a good correspondence between the estimates of total fertility made from the census and the DHS data, except in the Eastern Cape, Free State, North-West and Mpumalanga. The rankings of provinces by their total fertility, according to the two inquiries, are in reasonably good agreement.

\section{Table 7 about here}

\section{Trends in South African fertility: 1955-1998}

Using data on the age distribution of the population from the 1996 and 1970 South Africa Censuses, reverse-survival techniques can be applied to the data for all South African women, and for African South African women separately, to better understand the trends in South African fertility over the last fifty years and place the results derived above in an historical context.

\section{All South African women}

With appropriate assumptions (the most important of which is the requirement that no differential under-enumeration has occurred in particular age groups in the data being analysed), reverse-survival techniques can provide valuable insights into fertility trends for periods up to 15 years before a census or survey (Bogue 1993). The method is intuitively simple: if the level of mortality by age for the 15 years prior to the survey or census can be estimated accurately, it is possible to calculate the number of births that must have occurred in earlier years to give rise to the current population. Using estimates of South African mortality derived by Timæus, Dorrington, Bradshaw et al. (forthcoming), births for the period from 1981 to 1996 can be derived from the 1996 Census data. A similar exercise was performed using the data from the 1970 South Africa Census, using more approximate estimates of mortality based on the Princeton Regional Model Life Tables (Coale, Demeny and Vaughan 1983), assuming Level 12 for 1955-60, 
Level 13 for 1960-65 and Level 15 for 1965-70. The general level of mortality was chosen so that the resulting tables showed values of $\mathrm{e}_{0}$ and ${ }_{5} \mathrm{q}_{0}$ roughly in line with estimates for the population at the time.

Estimates of the age-specific fertility rates for each of the 15 years preceding the survey, and hence estimates of total fertility, were derived using a schedule of the fertility distribution in quinquennial groups to apportion the births by age of mother. The fertility distributions needed to do this for the period 1981 to 1996 were interpolated from the fertility estimates for 1996 (Table 6) and data for 1978 (South Africa 1983, p.115).

The reverse-survival estimates of fertility calculated using the 1970 Census data are more approximate, not only in their use of model life tables, but also because no published data on the distribution of fertility by age exist for this period. Estimates of the racial composition of South Africa for the period 1955-1970 were derived by interpolating between published estimates that are available for 1960 and 1970 (South Africa 1983, p.12). Sadie's (1973) estimates of fertility by population group and period were then combined using these weights and interpolation between them was used to derive annual national fertility schedules. Annual fertility schedules for Africans were interpolated directly between Sadie's estimates. Schedules for the first and last periods of each reverse-survival projection, for South Africans and African South Africans separately, are shown in Table 8.

Unfortunately, the 1987-9 DHS data do not readily lend themselves to analysis to support or refute the arguments presented here. Women were eligible for inclusion in that survey only if they were married, or if they had borne a child. Hence unmarried and childless women who would normally be included in the denominator in the calculation of age-specific fertility rates are overwhelmingly absent from these data.

\section{Table 8 about here}


The estimates derived from the application of the reverse-survival technique are shown in Figure 3, together with estimates published by Mostert, Hofmeyr, Oosthuizen et al (1998) and Sibanda and Zuberi (1999).

\section{Figure 3 about here}

The absence of reliable census data for South Africa between 1970 and 1996 creates a gap in our knowledge relating to the period 1970-1981. However, linear interpolation between the two series (to avoid errors associated with misreporting of infants' age, and under-enumeration at the youngest ages, we have interpolated using the values for 1966 and 1983) allows some conclusions to be drawn and enhances our understanding of the trend in South African fertility over the 50 years since 1948 .

Figure 3 indicates that the estimates we have derived for the 1950s and 1960s are indeed rough approximations as the variability in fertility estimates from one year to the next indicates. The very low levels of fertility estimated for 1968 and 1969 reflect the underenumeration of children under the age of 2 , while the pattern in the later years of the 1950s shows strong digit preference in the recording of children's ages. Despite these limitations, the estimates indicate that South African fertility has been in decline since the 1960s and that the pace of decline has increased since the early 1980s.

\section{African women}

Applying the same reverse-survival techniques to the African population produces the results shown in Figure 4. Given the racial composition of the South African population, it is not surprising that the trends shown in Figure 3 and Figure 4 are similar. The two back projections (and the interpolation between them) show clearly that the decline in African women's fertility began in the 1960s. At the beginning of that decade the total fertility of the African population was nearly 7 children per woman while by the end of the decade it was less than 6 . Fertility 
continued to fall slowly during the following decade. As in the general population, it has declined at a faster pace since the early 1980s.

While the pattern shown by our estimates is broadly similar to those shown by other estimates, some features are worthy of additional comments. First, although both sets are based on reverse survival of the 1996 Census data, the estimates presented here are lower than those produced by Sibanda and Zuberi, especially for the period 1982 to 1994. In a review of the initial estimates of fertility based on the 1996 census data, Dorrington, Nannan and Bradshaw (1999) suggest that Sibanda and Zuberi's estimates were most likely flawed by their use of North model life tables (rather than the usually used West); by their implausible application of the same level of North model life tables to all population groups; by their uncritical acceptance of the enumerated numbers and ages of children; and by their inadvertent linking of children to their mothers which would tend to inflate the estimates of fertility among older women. Apropos this last observation, Sibanda and Zuberi's estimates of fertility among African women aged 45-49 are almost four times higher than those we report here, and twice as high as those reported in the DHS. Second, our estimates suggest that total fertility has been consistently lower than was suggested by Mostert, van Tonder and Hofmeyr (1987) or, to look at this another way, that the decline in fertility occurred somewhat earlier than they believed.

\section{Figure 4 about here}

In addition, the use of reverse-survival techniques produce fertility estimates for the years immediately prior to the census that are substantially lower than those presented earlier. This suggests that, as Dorrington (1999) has also argued, a significant undercount of young children occurred in the 1996 Census that persists in the data despite the corrections made on the basis of the post-enumeration survey. Mostert, van Tonder and Hofmeyr (1987), in a reconstruction of the African South African population, estimate that only 62 per cent of children under the age of five were enumerated in 1980, whereas it is estimated that approximately three quarters of 
children under five were enumerated in 1970. The undercount of this age group in the 1996 Census was probably less severe. Dividing the estimate of total fertility in 1996 from the current fertility data in the census by that from the reverse-survival procedure suggests that the undercount of infants (aged less than one) in the 1996 South Africa Census was 22.9 per cent. For African infants, the equivalent estimate is 26.6 per cent. Since underenumeration is highest at the very youngest ages, it would suggest that the underenumeration of children aged less than five was somewhat less extreme than that in either 1970 or 1980.

The DHS collected birth histories from women aged 15 to 49. As the data on older women are truncated as one moves back in time, these birth histories cannot be used to calculate a series of estimates of total fertility. They can be used to calculate period indices of cumulative fertility by age 35 for the 15 years prior to the DHS. Figure 5 compares such estimates for the three fiveyear periods prior to the DHS with the equivalent measures computed by reverse-survival of the 1996 Census data

\section{Figure 5 about here}

The remarkable agreement between the two earlier estimates from the DHS and the census-based series inspires confidence about the quality of both the age distribution of African women in the census and the enumeration of African children aged between 5 and 15 . The most recent fertility estimates from the census seem a little low and provide further evidence that some underenumeration of young children and infants occurred in the census.

\section{Conclusions}

The 1996 South Africa Census and the 1998 South Africa Demographic and Health Survey (DHS) provide the first substantial data in more than a decade that allow the trend in and pattern of South African fertility to be investigated in detail. Deficiencies and errors in both data sets 
notwithstanding, we have estimated current and past levels of fertility in the country, for all South African women, and for African South African women separately.

The level of fertility more-or-less halved between the 1960s and 1996, to 3.2 children per woman nationally and 3.5 children per woman among African South Africans. These estimates are somewhat higher than other estimates published recently based on the 1998 DHS data (see Table 2). Moreover, although they are similar to previously published estimates based on the 1996 Census data, the age pattern of fertility that underlies them is very different from that apparent in the unadjusted data.

While minor differences exist in the characteristics of the populations covered by the DHS and the 1996 Census, the strong correspondence between the estimates of women's cumulative fertility to age 34 from the DHS and from the back projections of the 1996 Census leaves little scope for uncertainty about trends in South African fertility since the early-1980s. Past estimates of total fertility in South Africa have varied markedly and the results presented here do much to resolve uncertainty about the secular trend in South African fertility over the past few decades. Our estimates of pre-transitional fertility among African women made from the 1970 Census data agree quite well with the 'official' estimates of 6.7-6.8 shown in Table 1. However, fertility began to decline a little earlier than the official estimates suggest and dropped by 10 per cent before the end of the 1960s, marking the onset of the African fertility transition. Nevertheless, fertility fell slowly at first and most of the fall in the fertility of African women has occurred since the mid-1980s. Fertility in South Africa is now lower than elsewhere in sub-Saharan Africa. Equally, it is comparable with fertility in many middle-income countries in other parts of the developing world.

As with all fertility transitions, there is no monocausal explanation of the decline that has occurred. The South African population is more urbanised in 1998 than it was in 1970; contraceptive availability and use were high in 1998, while contraceptives were neither readily nor cheaply available in 1970; the social, political and economic fabric of South African society has 
changed beyond recognition over the last 30 years; and levels of education have increased. All these factors probably contributed to the decline.

However, when the South African fertility transition is viewed through the prism of these changes, the apparent anomaly of South African demography (why did fertility remain so high, and why was it relatively unresponsive to the introduction of the first family planning programme in the 1970s) is resolved to a degree. The South African fertility transition has run a long course of gradual change. The slowness of the transition up until the 1980s is more a reflection of the structural constraints on African women under apartheid, that is on their mobility, livelihoods and access to reproductive health delivery systems, than of any recalcitrance or lack of desire on the part of women to limit their fertility. From this perspective, the increased pace of fertility decline from the mid-1980s probably reflects the gradual freeing up of South African society since the mid-1970s, on the one hand, and the extension of the government's family planning programme to Africans in 1974 (and its subsequent relaunch in 1984), on the other. It is important to emphasise, however, that the level of fertility among African South Africans had begun to fall several years before the introduction of the first official family planning programme in 1974. In a similar vein, despite that programme being described as 'super-Asian' in its intensity (Caldwell and Caldwell 1993), one of the authors has argued elsewhere that little evidence exists to support the argument that the programme materially altered the pattern or trajectory of African fertility in the country (Moultrie 2001).

The decline in South African fertility reported here is important for several reasons. First, it establishes beyond doubt that South Africa, together with Zimbabwe and Botswana, is welladvanced in the transition from high to low fertility. Second, this reconstruction of South Africa's demographic past has confirmed that fertility in South Africa has been falling for several decades, although the evidence here would point to that decline having started sooner than was thought previously. Finally, the pace of the decline in recent years and the levels of fertility now being reported suggest that the absolute number of births in each population group every year has 
reached a maximum and is now declining. The implications for development agenda in the country are significant: in the next few years, the largest cohort of children will enter the schooling system, with declining numbers of children enrolling each year thereafter. Likewise, other infrastructural development planning needs to take this shift in the dynamics of the South African population into account.

The spread of the HIV epidemic will probably accelerate the future decline in South African fertility. In the 2001 antenatal survey, HIV prevalence among African South African women was estimated at 24.8 per cent (Department of Health 2002b). Recent evidence suggests that women infected with HIV have lower fertility as a result of secondary sterility and foetal loss brought on by the disease and its associated opportunistic infections (Zaba and Gregson 1998). Moreover, women who know or suspect that they are infected with HIV may choose to avoid childbearing, although the difficulties experienced by sub-Saharan African women (and HIV positive women in particular) in negotiating reproductive preferences and outcomes with their partners have been well documented (see, for example, Keogh, Allen, Almedal et al. (1994)). In any event, it is anticipated that HIV/AIDS morbidity and mortality will be highest among women in their thirties, thereby reducing the number of children borne by older women. Indeed, some indication of the effects of HIV/AIDS on fertility can be observed from the fact that, according to a Department of Health report into maternal mortality, 82 out of 565 maternal deaths in 1998 were recorded as due to AIDS (although HIV/AIDS-related deaths are almost certainly underreported) and more than 87 per cent of these women, nearly three quarters of whom were aged less than thirty had had fewer than three deliveries (Department of Health 1999).

There is still considerable uncertainty about the nature of the linkages between HIV and fertility in sub-Saharan Africa, and much more research in this area is needed. The data being collected at the INDEPTH and other demographic surveillance sites (of which there are two in 
South Africa) may eventually be able to shed some light on these questions. The changing demography of South Africa makes the answering of these question all the more urgent. 


\section{References}

Beinart, William. 1994. Twentieth-Century South Africa. Oxford: Oxford University Press.

Bogue, Donald J. 1993. Fertility measurement by reverse survival of age-sex distributions, in Bogue, Donald, J., Eduardo E. Arriaga and Douglas Anderton, L. (eds.), Readings in Population Research Methodology. Vol. 3. New York: United Nations Fund for Population Activities, pp. 11/39 - 11/42.

Caldwell, John C. and Pat Caldwell. 1993. The South African fertility decline, Population and Development Review 19(2):225-262.

Chimere-Dan, Orieji. 1993a. Racial patterns of fertility decline in South Africa, in International Population Conference 1993, Montreal. Vol. 1. Liège: International Union for the Scientific Study of Population, pp. 43-51.

Chimere-Dan, Orieji. 1993b. Population policy in South Africa, Studies in Family Planning 24(1):3139.

Chimere-Dan, Orieji. 1994. Population policy in a divided society: The South African experience, Paper presented at Annual Meeting of the Population Association of America. Miami, Florida, May 5-7, 1994.

Coale, Ansley J., Paul Demeny and Barbara Vaughan. 1983. Regional Model Life Tables and Stable Populations. New York: Academic Press.

Department of Health. 1999. Saving Mothers: Report on Confidential Enquiries into Maternal Deaths in South Africa, 1998. Pretoria: Department of Health.

Department of Health. 2002a. South Africa Demographic and Health Survey 1998: Full Report. Pretoria: Department of Health.

Department of Health. 2002b. Summary Report: National HIV and Syphilis Seroprevalence Survey in South Africa, 2001. Pretoria: Department of Health.

Dorrington, Robert E. 1999. Who was counted in? Some possible deficiencies with the 1996 South African Census results, Paper presented at Actuarial Society of South Africa Convention. Johannesburg, 2-3 November 1999.

Dorrington, Robert E., Nadine Nannan and Debbie Bradshaw. 1999. Current fertility rates in South Africa: 1996 Census revisited, Paper presented at Workshop on Phase 2 of Census 1996 Review. Johannesburg, South Africa, 3 - 4 December 1999.

El-Badry, M.A. 1961. Failure of enumerators to make entries of zero: errors in recoding childless cases in population censuses, Journal of the American Statistical Association 56(296):909-924.

Feeney, Griffith. 1998. A New Interpretation of Brass' P/F Ratio Method Applicable when Fertility is Declining. http://www.gfeeney.com/notes/pfnote/pfnote.htm. Accessed: 11 January 2000.

Fuller, Bruce. and Xiaoyan Liang. 1999. Which girls stay in school? The influence of family economy, social demands and ethnicity in South Africa, in Bledsoe, C.H., J.B. Casterline, J.A. Johnson-Kuhn and J.G. Haaga (eds.), Critical Perspectives on Schooling and Fertility in the Developing World. Washington DC: National Academy Press, pp. 181-215.

Garenne, Michel, Stephen M. Tollman and Kathleen Kahn. 2000. Premarital fertility in rural South Africa: A challenge to existing population policy, Studies in Family Planning 31(1):4754.

Kaufman, Carol E. 1996. The Politics and Practice of Reproductive Control in South Africa: A Multilevel Analysis of Fertility and Contraceptive Use. Unpublished PhD thesis, Ann Arbor: University of Michigan.

Kaufman, Carol E. 1998. Contraceptive use in South Africa under apartheid, Demography 35(4):421-434.

Kaufman, Carol E. 2000. Reproductive control in apartheid South Africa, Population Studies 54(1):105-114. 
Keogh, P., S. Allen, C. Almedal and B. Temahagili. 1994. The social impact of HIV infection on women in Kigali, Rwanda: A prospective study, Social Science \& Medicine 38(8):1047-1053.

Lipton, Merle. 1985. Capitalism and Apartheid: South Africa, 1910-1986. Aldershot: Wildwood House.

Lötter, J.M. and J.L. van Tonder. 1976. Fertility and Family Planning among Blacks in South Africa: 1974. Report S-39. Pretoria: Human Sciences Research Council.

Lucas, David. 1992. Fertility and family planning in Southern and Central Africa, Studies in Family Planning 23(3):145-158.

Mencarini, Letizia. 1999. An analysis of fertility and infant mortality in South Africa based on 1993 LSDS data, Paper presented at Third African Population Conference. Durban, South Africa, 6 - 10 December 1999. Union for African Population Studies. Vol. 1:109127.

Mostert, W.P., B.E. Hofmeyr, J.S. Oosthuizen and J.A. van Zyl. 1998. Demography: Textbook for the South African Student. Pretoria: Human Sciences Research Council.

Mostert, W.P. and J.M. Lötter (eds). 1990. South Africa's Demographic Future. Pretoria: Human Sciences Research Council.

Mostert, W.P., J.L. van Tonder and B.E. Hofmeyr. 1987. Rekonstruksie van die Sensusouderdomstrukture van die Suid-Afrikaanse Swart Bevolking: 1936 tot 1985 Reconstruction of the Census Age Structure of the South African Black Population: 1936 to 19857. Report S-153 (1987). Pretoria: Human Sciences Research Council.

Mostert, W.P., J.L. van Tonder and B.E. Hofmeyr. 1988. Demographic trends in South Africa, in Marais, H.C. (ed.). South Africa: Perspectives on the Future. Pinetown: Owen Burgess, pp. 5986.

Moultrie, Tom A. 2001. Racism and reproduction: The institutional effects of apartheid on the South African fertility decline, Paper presented at International Union for the Scientific Study of Population, XXIV General Population Conference. Salvador de Bahia, Brazil, 18 - 24 August 2001.

Moultrie, Tom A. and Ian M. Timæus. 2002. Trends in South African fertility between 1970 and 1998: An analysis of the 1996 Census and the 1998 Demographic and Health Survey. Cape Town: Medical Research Council. http://www.mrc.ac.za/bod/trends.pdf.

Newell, Colin. 1988. Methods and Models in Demography. Chichester: John Wiley \& Sons.

Oosthuizen, Kobus. 2000. Demographic changes and sustainable land use in South Africa, Genus 56(3-4):81-107.

Preston-Whyte, Eleanor. 1988. Culture, context and behaviour: Anthropological perspectives on fertility in Southern Africa, Southern African Journal of Demography 2(1):13-23.

Preston-Whyte, Eleanor. 1994. Qualitative studies of fertility and family planning in South Africa, Paper presented at Population Association of America 1994 Annual Meeting. Miami, Florida, May 5-7, 1994.

Sadie, Jan L. 1950. The political arithmetic of the South African population, Journal of Racial Affairs 1(4):3-8.

Sadie, Jan L. 1973. Projections of the South African Population 1970 - 2020. Johannesburg: Industrial Development Corporation.

SALDRU. 1994. South Africa Integrated Household Survey 1993. Cape Town: University of Cape Town, Southern Africa Labour and Development Research Unit.

Sibanda, Amson and Tukufu Zuberi. 1999. Contemporary fertility levels and trends in South Africa: Evidence from reconstructed census birth histories, Paper presented at Third African Population Conference. Durban, South Africa, 6 - 10 December 1999. Union for African Population Studies. Vol. 1:79-108.

South Africa, Republic of. 1983. Report of the Science Committee of the President's Council on Demographic Trends in South Africa. Cape Town: Government Printer. 
Statistics South Africa. 1998a. The People of South Africa: Population Census 1996 - Calculating the Undercount in Census '96. Report 03-01-18 (1996). Pretoria: Statistics South Africa.

Statistics South Africa. 1998b. The People of South Africa: Population Census 1996, 10\% Sample of Unit Records. Report 03-01-13 (1996). Pretoria: Statistics South Africa.

Timæus, Ian M., Rob Dorrington, Debbie Bradshaw and Nadine Nannan. forthcoming. Mortality in South Africa, 1985-1997: From Apartheid to AIDS. Cape Town: Medical Research Council.

Udjo, Eric O. 1997. Fertility and Mortality Trends in South Africa: The Evidence from the 1995 October Household Survey, and Implications on Population Projections. Pretoria: Statistics South Africa.

Udjo, Eric O. 1998. The People of South Africa - Population Census 1996: Additional Evidence Regarding Fertility and Mortality Trends in South Africa and Implications for Population Projections. Pretoria: Statistics South Africa, Directorate of Analysis.

United Nations. 1993. Estimates of Fertility Based on Information About Children Ever Born, in Bogue, Donald J., Eduardo E. Arriaga and Douglas L. Anderton (eds.), Readings in Population Research Methodology. Vol. 3. Chicago: United Nations Population Fund, pp. $11 / 11-11 / 17$.

van der Vliet, Virginia. 1991. Traditional husbands, modern wives - constructing marriages in a South African township, African Studies 50(1-2):219-241.

van Wyk, J.J. 1980. Fertiliteit en Gesinsbeplanning onder Swartes in Suid-Afrika: 1976 [Fertility and Family Planning among Blacks in South Africa: 1976]. Report SN-196. Pretoria: Human Sciences Research Council.

Verwoerd, Hendrik F. 1978 (1962). Speech in the House of Assembly on January 23rd 1962, in Lever, Henry (ed.). Readings in South African Society. Johannesburg: Jonathan Ball, pp. 179190.

Zaba, Basia. 1981. Use of the Relational Gompertz. Model in Analysing Fertility Data Collected in Retrospective Surveys. Centre for Population Studies Research Paper 81-2. London: Centre for Population Studies, London School of Hygiene \& Tropical Medicine.

Zaba, Basia and Simon Gregson. 1998. Measuring the impact of HIV on fertility in Africa, AIDS 12(suppl 1):S41-S50. 
Table 1 “Official” estimates of total fertility in South Africa, 1945-95

\begin{tabular}{lcc}
\hline Period & All South African women & African women \\
\hline $1945-50$ & 6.0 & 6.8 \\
$1950-55$ & 6.1 & 6.8 \\
$1955-60$ & 6.0 & 6.7 \\
$1960-65$ & 6.0 & 6.7 \\
$1965-70$ & 5.8 & 6.5 \\
$1970-75$ & 5.5 & 6.3 \\
$1975-80$ & 4.9 & 5.8 \\
$1980-85$ & 4.6 & $5.4-5.6$ \\
$1985-90$ & 4.0 & 4.6 \\
$1990-95$ & 3.5 & $4.0^{*}$ \\
\hline
\end{tabular}

* Oosthuizen (2000), citing the same sources, gives a figure of 3.6 for Africans in 1990-95. This figure is implausible, given that total fertility in the country was still estimated as 3.5 children per woman. Hence, his discussion on the "plummeting" decline in African fertility after 1980 appears to be based on flawed data.

Source: Mostert, Hofmeyr, Oosthuizen et al. (1998) for All South Africans and Africans 1985-95; Mostert, van Tonder and Hofmeyr (1987) for Africans 1945-85. The higher value for Africans in 1980-85 comes from the 1987 publication, the lower from 1988. 
Table 2 Summary of estimates of total fertility in South Africa using data collected since 1993

\begin{tabular}{|c|c|c|c|c|}
\hline Author and year of publication & Population & Data Source & $\begin{array}{l}\text { Year(s) to } \\
\text { which estimate } \\
\text { applies }\end{array}$ & $\begin{array}{l}\text { Total } \\
\text { Fertility }\end{array}$ \\
\hline Sibanda and Zuberi (1999) & African & 1996 Census & 1985 & 5.2 \\
\hline Mencarini (1999) & African & 1993 LSDS & $1984-88$ & 4.8 \\
\hline Sibanda and Zuberi (1999) & African & 1996 Census & 1990 & 4.7 \\
\hline Mencarini (1999) & African & 1993 LSDS & 1989-93 & 3.7 \\
\hline Sibanda and Zuberi (1999) & African & 1996 census & 1995 & 3.1 \\
\hline Dorrington, Nannan and Bradshaw (1999) & African & 1996 Census & 1996 & 3.6 \\
\hline Sibanda and Zuberi (1999) & African & 1996 Census & 1996 & 3.0 \\
\hline Department of Health (2002a) & African & 1998 DHS & $1996-8$ & 3.1 \\
\hline Udjo (1997) & All & 1995 OHS & 1980 & 4.2 \\
\hline Udjo (1997) & All & 1995 OHS & 1985 & 3.5 \\
\hline Sibanda and Zuberi (1999) & All & 1996 Census & 1985 & 4.5 \\
\hline Udjo (1997) & All & 1995 OHS & 1990 & 3.3 \\
\hline Sibanda and Zuberi (1999) & All & 1996 Census & 1990 & 4.2 \\
\hline Udjo (1997) & All & 1995 OHS & 1995 & 3.2 \\
\hline Sibanda and Zuberi (1999) & All & 1996 Census & 1995 & 2.9 \\
\hline Udjo (1998) & All & 1996 Census & 1996 & 3.3 \\
\hline Dorrington, Nannan and Bradshaw (1999) & All & 1996 Census & 1996 & 3.2 \\
\hline Sibanda and Zuberi (1999) & All & 1996 Census & 1996 & 2.8 \\
\hline Department of Health (2002a) & All & 1998 DHS & 1996-8 & 2.9 \\
\hline
\end{tabular}

LSDS = Living Standards and Development Study; OHS = October Household Survey.

Source: As per cited references 
Table 3 Background characteristics of South African women aged 15-49

\begin{tabular}{|c|c|c|c|c|c|c|}
\hline \multirow{2}{*}{$\begin{array}{l}\text { Backeground } \\
\text { Characteristic }\end{array}$} & \multicolumn{3}{|c|}{$\begin{array}{l}\text { DHS Data } \\
\text { All South African women 15-49 }\end{array}$} & \multicolumn{3}{|c|}{$\begin{array}{l}\text { Census Data } \\
\text { All South African women 15-49 }\end{array}$} \\
\hline & Weighted \% & Weighted N & Unweighted $N$ & Weighted \% & Weighted $N$ & Unweighted $N$ \\
\hline \multicolumn{7}{|l|}{ Age } \\
\hline $15-19$ & 19.2 & 2249 & 2373 & 19.5 & 2135672 & 190557 \\
\hline $20-24$ & 17.7 & 2075 & 2086 & 18.9 & 2067653 & 182607 \\
\hline $25-29$ & 15.8 & 1857 & 1811 & 16.3 & 1790412 & 158317 \\
\hline $30-34$ & 14.1 & 1654 & 1616 & 14.8 & 1617576 & 144323 \\
\hline $35-39$ & 13.9 & 1636 & 1628 & 12.6 & 1375399 & 123101 \\
\hline $40-44$ & 11.0 & 1294 & 1255 & 10.1 & 1105325 & 99650 \\
\hline $45-49$ & 8.3 & 970 & 966 & 7.9 & 863268 & 78684 \\
\hline \multicolumn{7}{|l|}{ Residence } \\
\hline Urban & 60.5 & 7095 & 6518 & 57.7 & 6321903 & 565041 \\
\hline Non-urban & 39.5 & 4640 & 5217 & 42.3 & 4633401 & 412198 \\
\hline \multicolumn{7}{|l|}{ Province (de facto) } \\
\hline Western Cape & 10.2 & 1193 & 919 & 10.2 & 1120698 & 102114 \\
\hline Eastern Cape & 13.3 & 1566 & 2756 & 14.6 & 1600910 & 142883 \\
\hline Northern Cape & 2.2 & 253 & 1041 & 2.0 & 221107 & 18758 \\
\hline Free State & 6.5 & 763 & 936 & 6.6 & 721896 & 65760 \\
\hline KwaZulu-Natal & 20.1 & 2364 & 1826 & 21.0 & 2296584 & 200083 \\
\hline North West & 7.7 & 909 & 931 & 8.1 & 891976 & 80913 \\
\hline Gauteng & 21.7 & 2552 & 1057 & 19.4 & 2120387 & 190981 \\
\hline Mpumalanga & 7.0 & 819 & 1131 & 6.8 & 749418 & 65977 \\
\hline Northern Province & 11.2 & 1316 & 1138 & 11.2 & 1232330 & 109770 \\
\hline \multicolumn{7}{|l|}{ Province (de jure) } \\
\hline Western Cape & 10.3 & 1210 & 953 & 10.0 & 1093522 & 99748 \\
\hline Eastern Cape & 13.2 & 1553 & 2728 & 14.3 & 1561831 & 139716 \\
\hline Northern Cape & 2.4 & 279 & 1038 & 2.0 & 214823 & 18269 \\
\hline Free State & 6.7 & 787 & 951 & 6.5 & 707481 & 64506 \\
\hline KwaZulu-Natal & 20.0 & 2345 & 1813 & 20.4 & 2230458 & 194533 \\
\hline North West & 7.6 & 894 & 927 & 8.0 & 875358 & 79401 \\
\hline Gauteng & 21.6 & 2534 & 1063 & 19.0 & 2084731 & 187788 \\
\hline Mpumalanga & 7.0 & 822 & 1134 & 6.8 & 742996 & 65411 \\
\hline Northern Province & 11.0 & 1294 & 1119 & 11.0 & 1202493 & 107278 \\
\hline Other country & 0.0 & 4 & 2 & 2.2 & 241613 & 20589 \\
\hline Missing & 0.1 & 12 & 7 & 0.0 & 0 & 0 \\
\hline \multicolumn{7}{|l|}{ Education } \\
\hline No education & 6.8 & 804 & 810 & 11.5 & 1259929 & 111956 \\
\hline Primary & 24.8 & 2916 & 3134 & 23.6 & 2587923 & 230455 \\
\hline Secondary & 60.5 & 7103 & 6929 & 55.3 & 6062741 & 541518 \\
\hline Higher & 7.8 & 912 & 862 & 5.9 & 649052 & 58166 \\
\hline Other / Missing & 0.0 & 0 & 0 & 3.6 & 395660 & 35144 \\
\hline \multicolumn{7}{|l|}{ Population group } \\
\hline African & 77.9 & 9147 & 8993 & 76.4 & 8369644 & 744577 \\
\hline Coloured & 10.2 & 1201 & 1533 & 9.2 & 1011770 & 90343 \\
\hline White & 7.8 & 916 & 755 & 10.8 & 1179002 & 105736 \\
\hline Asian & 3.5 & 406 & 393 & 2.8 & 305130 & 28533 \\
\hline Missing & 0.6 & 66 & 61 & 0.8 & 89759 & 8050 \\
\hline Total & 100.0 & 11735 & 11735 & 100.0 & 10955305 & 977239 \\
\hline
\end{tabular}


Table 4 Mean children ever borne by women aged 15-49 by age and population group

\begin{tabular}{|c|c|c|c|c|c|c|}
\hline \multirow{3}{*}{ Age } & \multicolumn{3}{|c|}{ African women } & \multicolumn{3}{|c|}{ Coloured women } \\
\hline & Unadjusted & Adjusted & 1998 & Unadjusted & Adjusted & 1998 DHS \\
\hline & 1996 Census & 1996 Census & DHS & 1996 Census & 1996 Census & \\
\hline $15-19$ & 0.23 & 0.16 & 0.15 & 0.18 & 0.14 & 0.16 \\
\hline $20-24$ & 0.91 & 0.74 & 0.83 & 0.79 & 0.68 & 0.80 \\
\hline $25-29$ & 1.74 & 1.55 & 1.65 & 1.52 & 1.39 & 1.33 \\
\hline $30-34$ & 2.69 & 2.50 & 2.63 & 2.24 & 2.11 & 2.12 \\
\hline $35-39$ & 3.48 & 3.27 & 3.46 & 2.82 & 2.68 & 2.66 \\
\hline $40-44$ & 4.16 & 3.92 & 3.81 & 3.27 & 3.12 & 3.07 \\
\hline \multirow[t]{2}{*}{$45-49$} & 4.61 & 4.33 & 4.46 & 3.74 & 3.60 & 3.42 \\
\hline & \multicolumn{3}{|c|}{ Indian/Asian women } & \multicolumn{3}{|c|}{ White women } \\
\hline \multirow[t]{2}{*}{ Age } & Unadjusted & Adjusted & 1998 & Unadjusted & Adjusted & 1998 DHS \\
\hline & 1996 Census & 1996 Census & DHS & 1996 Census & 1996 Census & \\
\hline $15-19$ & 0.07 & 0.05 & 0.03 & 0.06 & 0.04 & 0.02 \\
\hline $20-24$ & 0.53 & 0.33 & 0.47 & 0.35 & 0.29 & 0.19 \\
\hline $25-29$ & 1.34 & 1.20 & 1.26 & 1.02 & 0.92 & 1.37 \\
\hline $30-34$ & 2.06 & 1.94 & 2.24 & 1.67 & 1.58 & 1.82 \\
\hline $35-39$ & 2.43 & 2.32 & 2.79 & 2.05 & 1.96 & 2.11 \\
\hline $40-44$ & 2.71 & 2.61 & 2.55 & 2.24 & 2.15 & 2.33 \\
\hline $45-49$ & 2.92 & 2.78 & 2.84 & 2.40 & 2.31 & 2.59 \\
\hline
\end{tabular}

Source: Authors' calculations from 1998 DHS and 1996 Census data files 
Table 5 Age-specific and total fertility for women aged 15-49 by population group, 1996

\begin{tabular}{|c|c|c|c|c|c|c|}
\hline \multirow{3}{*}{ Age } & \multicolumn{3}{|c|}{ African women } & \multicolumn{3}{|c|}{ Coloured women } \\
\hline & Unadjusted & Adjusted 1996 & 1998 & Unadjusted & Adjusted 1996 & 1998 \\
\hline & 1996 Census & Census & DHS & 1996 Census & Census & DHS \\
\hline $15-19$ & 0.050 & 0.086 & 0.081 & 0.048 & 0.068 & 0.081 \\
\hline $20-24$ & 0.104 & 0.159 & 0.139 & 0.105 & 0.144 & 0.162 \\
\hline $25-29$ & 0.117 & 0.159 & 0.142 & 0.121 & 0.133 & 0.128 \\
\hline $30-34$ & 0.127 & 0.135 & 0.119 & 0.095 & 0.097 & 0.083 \\
\hline $35-39$ & 0.113 & 0.102 & 0.088 & 0.066 & 0.060 & 0.042 \\
\hline $40-44$ & 0.096 & 0.050 & 0.038 & 0.050 & 0.023 & 0.010 \\
\hline $45-49$ & 0.080 & 0.007 & 0.013 & 0.035 & 0.002 & 0.001 \\
\hline \multirow[t]{2}{*}{ Total } & 3.44 & 3.49 & 3.11 & 2.60 & 2.64 & 2.53 \\
\hline & \multicolumn{3}{|c|}{ Indian/Asian women } & \multicolumn{3}{|c|}{ White women } \\
\hline \multirow[t]{2}{*}{ Age } & Unadjusted & Adjusted 1996 & 1998 & Unadjusted & Adjusted 1996 & 1998 \\
\hline & 1996 Census & Census & DHS & 1996 Census & Census & DHS \\
\hline $15-19$ & 0.013 & 0.024 & 0.026 & 0.013 & 0.019 & 0.020 \\
\hline $20-24$ & 0.087 & 0.120 & 0.138 & 0.063 & 0.089 & 0.087 \\
\hline $25-29$ & 0.112 & 0.185 & 0.095 & 0.110 & 0.151 & 0.185 \\
\hline $30-34$ & 0.086 & 0.085 & 0.066 & 0.082 & 0.088 & 0.069 \\
\hline $35-39$ & 0.048 & 0.045 & 0.036 & 0.046 & 0.031 & 0.016 \\
\hline $40-44$ & 0.035 & 0.023 & 0.000 & 0.035 & 0.016 & 0.000 \\
\hline $45-49$ & 0.035 & 0.008 & 0.000 & 0.033 & 0.010 & 0.000 \\
\hline Total & 2.09 & 2.45 & 1.80 & 1.91 & 2.02 & 1.88 \\
\hline
\end{tabular}

Source: Authors' calculations from 1998 DHS and 1996 Census data files 
Table 6 Age-specific and total fertility, South Africa, 1996

\begin{tabular}{llllllllc}
\hline Age & $15-19$ & $20-24$ & $25-29$ & $30-34$ & $35-39$ & $40-44$ & $45-49$ & Total fertility \\
\hline 1996 Census & 0.078 & 0.151 & 0.156 & 0.125 & 0.087 & 0.042 & 0.007 & 3.23 \\
1998 DHS & 0.076 & 0.139 & 0.142 & 0.109 & 0.074 & 0.029 & 0.009 & 2.89 \\
\hline
\end{tabular}

Source: Authors' calculations from 1998 DHS and 1996 Census data files 
Table 7 Estimates of age-specific and total fertility by province of usual residence, 1996

\begin{tabular}{|c|c|c|c|c|c|c|}
\hline \multirow[b]{2}{*}{ Age } & \multicolumn{2}{|c|}{ Western Cape } & \multicolumn{2}{|c|}{ Eastern Cape } & \multicolumn{2}{|c|}{ Northern Cape } \\
\hline & 1996 Census & 1998 DHS & 1996 Census & 1998 DHS & 1996 Census & 1998 DHS \\
\hline $15-19$ & 0.055 & 0.067 & 0.079 & 0.079 & 0.071 & 0.076 \\
\hline $20-24$ & 0.131 & 0.120 & 0.170 & 0.146 & 0.155 & 0.156 \\
\hline $25-29$ & 0.122 & 0.121 & 0.178 & 0.175 & 0.143 & 0.148 \\
\hline $30-34$ & 0.088 & 0.092 & 0.154 & 0.141 & 0.105 & 0.092 \\
\hline $35-39$ & 0.053 & 0.051 & 0.116 & 0.107 & 0.064 & 0.044 \\
\hline $40-44$ & 0.019 & 0.007 & 0.056 & 0.037 & 0.024 & 0.015 \\
\hline $45-49$ & 0.002 & 0.000 & 0.008 & 0.008 & 0.002 & 0.005 \\
\hline \multirow[t]{2}{*}{ Total } & 2.35 & 2.29 & 3.80 & 3.47 & 2.82 & 2.68 \\
\hline & \multicolumn{2}{|c|}{ Free State } & \multicolumn{2}{|c|}{ KwaZulu-Natal } & \multicolumn{2}{|c|}{ North-West } \\
\hline Age & 1996 Census & 1998 DHS & 1996 Census & 1998 DHS & 1996 Census & 1998 DHS \\
\hline $15-19$ & 0.060 & 0.055 & 0.078 & 0.092 & 0.076 & 0.060 \\
\hline $20-24$ & 0.147 & 0.103 & 0.157 & 0.148 & 0.151 & 0.137 \\
\hline $25-29$ & 0.142 & 0.116 & 0.157 & 0.158 & 0.145 & 0.091 \\
\hline $30-34$ & 0.107 & 0.094 & 0.130 & 0.109 & 0.114 & 0.108 \\
\hline $35-39$ & 0.067 & 0.043 & 0.094 & 0.098 & 0.078 & 0.076 \\
\hline $40-44$ & 0.025 & 0.027 & 0.043 & 0.042 & 0.033 & 0.016 \\
\hline $45-49$ & 0.002 & 0.000 & 0.006 & 0.019 & 0.004 & 0.000 \\
\hline \multirow[t]{2}{*}{ Total } & 2.75 & 2.19 & 3.32 & 3.33 & 3.00 & 2.44 \\
\hline & \multicolumn{2}{|c|}{ Gauteng } & \multicolumn{2}{|c|}{ Mpumalanga } & \multicolumn{2}{|c|}{ Limpopo } \\
\hline Age & 1996 Census & 1998 DHS & 1996 Census & 1998 DHS & 1996 Census & 1998 DHS \\
\hline $15-19$ & 0.059 & 0.052 & 0.093 & 0.100 & 0.101 & 0.090 \\
\hline $20-24$ & 0.131 & 0.125 & 0.170 & 0.129 & 0.181 & 0.179 \\
\hline $25-29$ & 0.126 & 0.136 & 0.161 & 0.124 & 0.180 & 0.187 \\
\hline $30-34$ & 0.096 & 0.084 & 0.128 & 0.136 & 0.154 & 0.142 \\
\hline $35-39$ & 0.062 & 0.047 & 0.089 & 0.097 & 0.118 & 0.089 \\
\hline $40-44$ & 0.024 & 0.024 & 0.039 & 0.015 & 0.059 & 0.059 \\
\hline $45-49$ & 0.003 & 0.000 & 0.005 & 0.016 & 0.009 & 0.029 \\
\hline Total & 2.50 & 2.34 & 3.42 & 3.09 & 4.01 & 3.88 \\
\hline
\end{tabular}

Source: Authors' calculations from 1998 DHS and 1996 Census data files 
Table 8 Distributions by age of fertility used in the reverse-survival projections

\begin{tabular}{lllllllll}
\hline & \multicolumn{3}{c}{1956} & \multicolumn{3}{c}{1970} & \multicolumn{2}{c}{1982} \\
Age & All & Africans & All & Africans & All & Africans & All & Africans \\
\hline $15-19$ & 0.053 & 0.045 & 0.061 & 0.056 & 0.074 & 0.078 & 0.102 & 0.123 \\
$20-24$ & 0.213 & 0.190 & 0.228 & 0.212 & 0.234 & 0.218 & 0.227 & 0.227 \\
$25-29$ & 0.233 & 0.220 & 0.251 & 0.241 & 0.261 & 0.240 & 0.244 & 0.228 \\
$30-34$ & 0.195 & 0.198 & 0.203 & 0.207 & 0.199 & 0.200 & 0.199 & 0.193 \\
$35-39$ & 0.156 & 0.167 & 0.143 & 0.153 & 0.133 & 0.148 & 0.140 & 0.146 \\
$40-44$ & 0.096 & 0.111 & 0.075 & 0.084 & 0.069 & 0.080 & 0.072 & 0.072 \\
$45-49$ & 0.054 & 0.069 & 0.040 & 0.048 & 0.030 & 0.037 & 0.015 & 0.010 \\
\hline
\end{tabular}

Source: Derived from Sadie (1973), South Africa (1983) and Tables 5 and 6. 

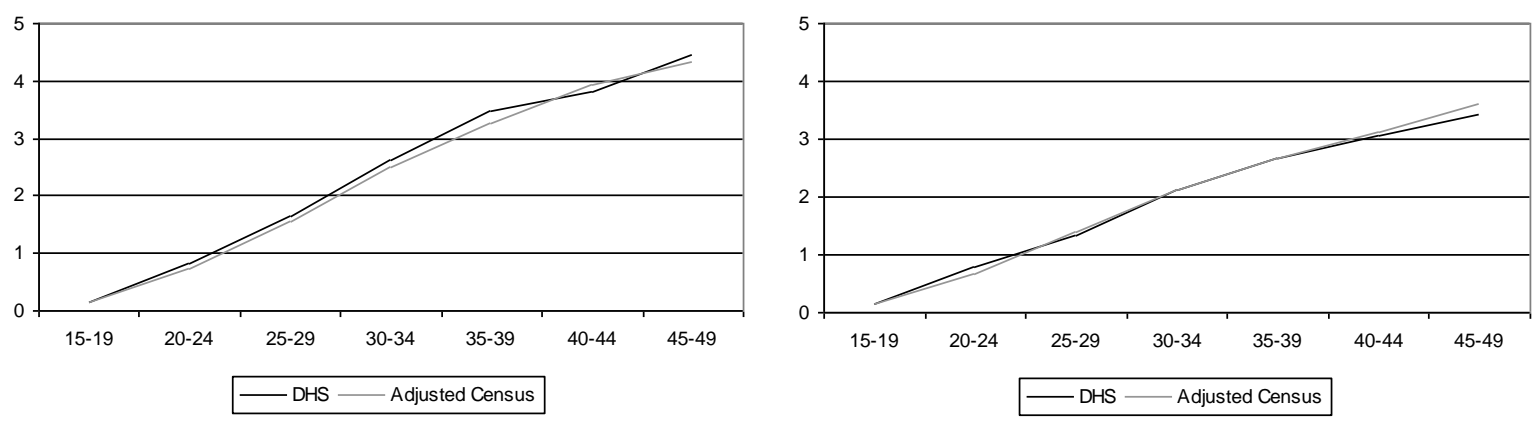

Indian/Asian women

White women
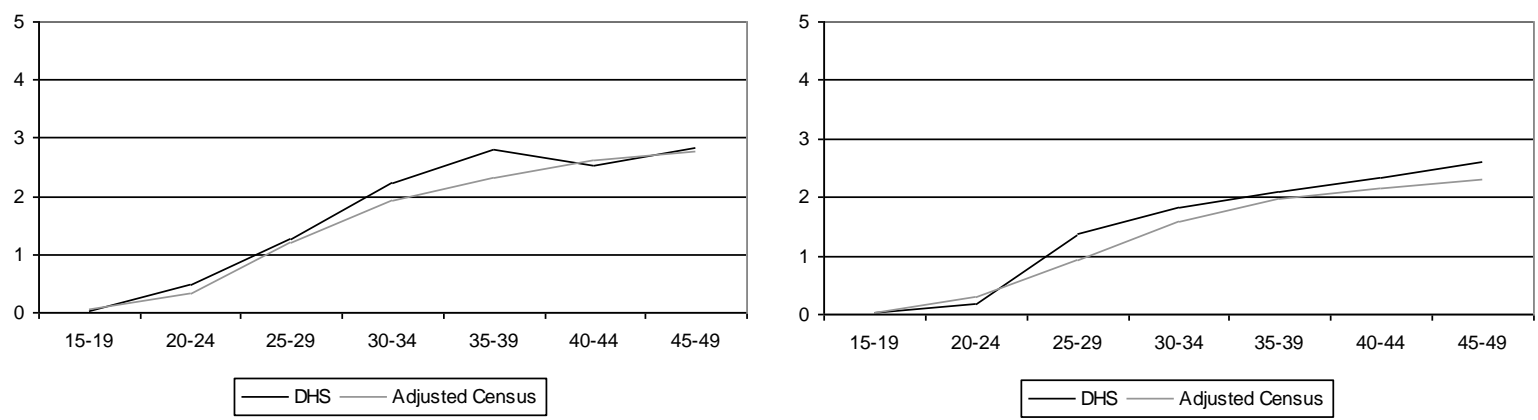

Figure 1 Mean children ever borne, by age group and population group

Source: Authors' calculations from 1998 DHS and 1996 Census data files 
African women

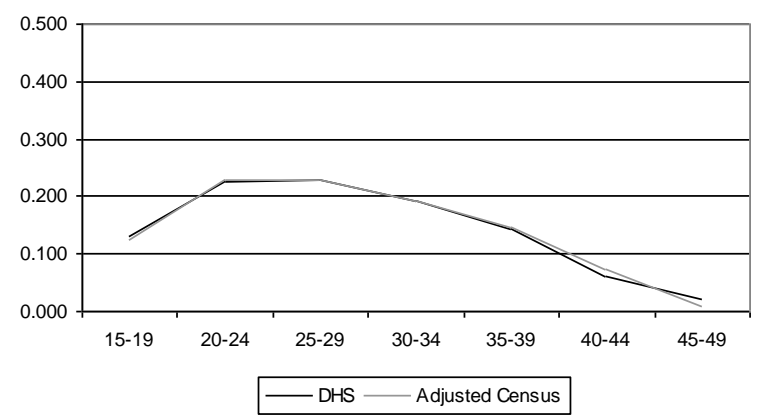

Indian/Asian women

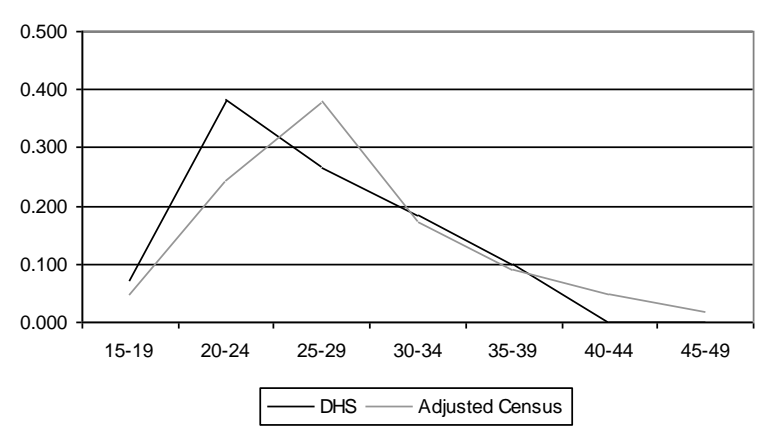

Coloured women

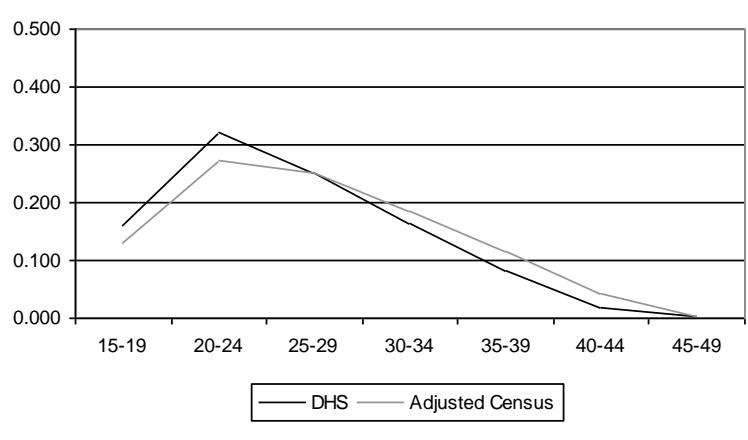

White women

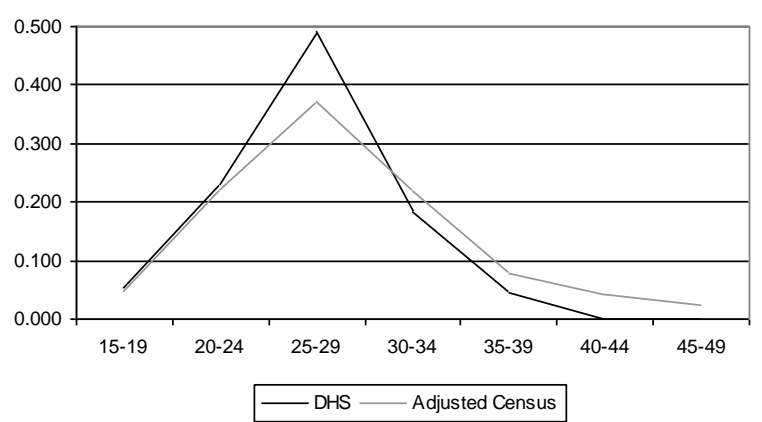

Figure 2 Percent distribution of fertility according to age by population group, 1996

Source: Authors' calculations from 1998 DHS and 1996 Census data files 


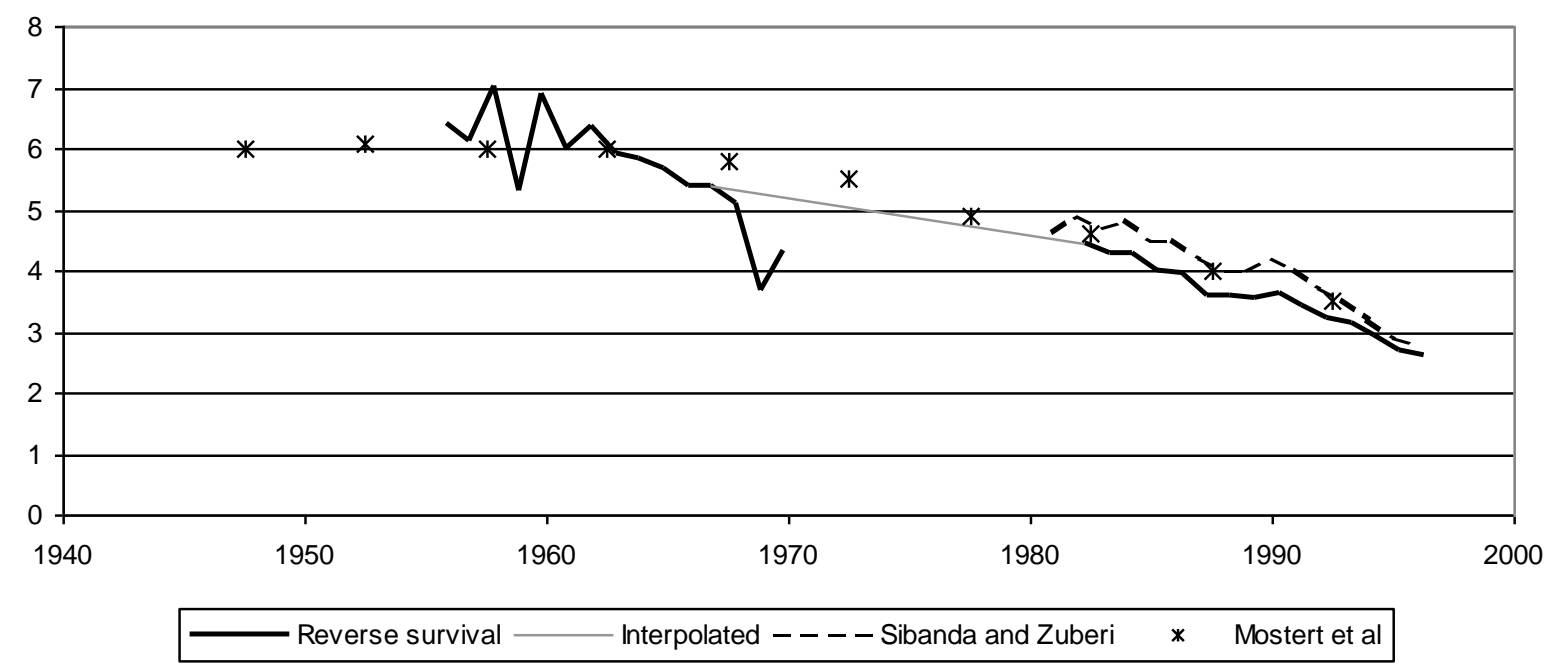

Figure 3 Trends in total fertility, all South African women, 1948-1996

Source: $\quad$ Authors' calculations from 1998 DHS and 1996 Census data files, Mostert, Hofmeyr, Oosthuizen et al. (1998), Sibanda and Zuberi (1999). 


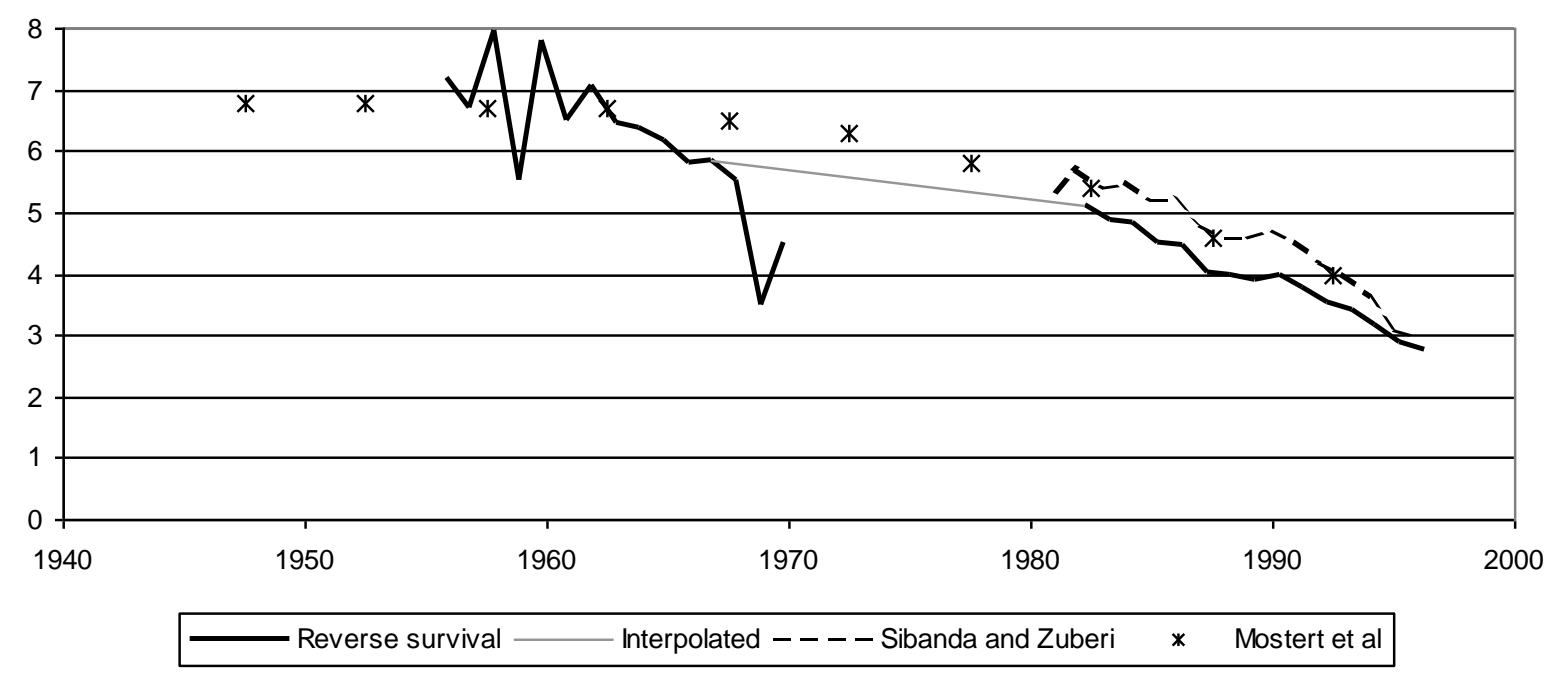

Figure 4 Trends in total fertility, African South African women, 1948-1996

Source: Authors' calculations from 1998 DHS and 1996 Census data files, Mostert, Hofmeyr, Oosthuizen et al. (1998), Sibanda and Zuberi (1999). 


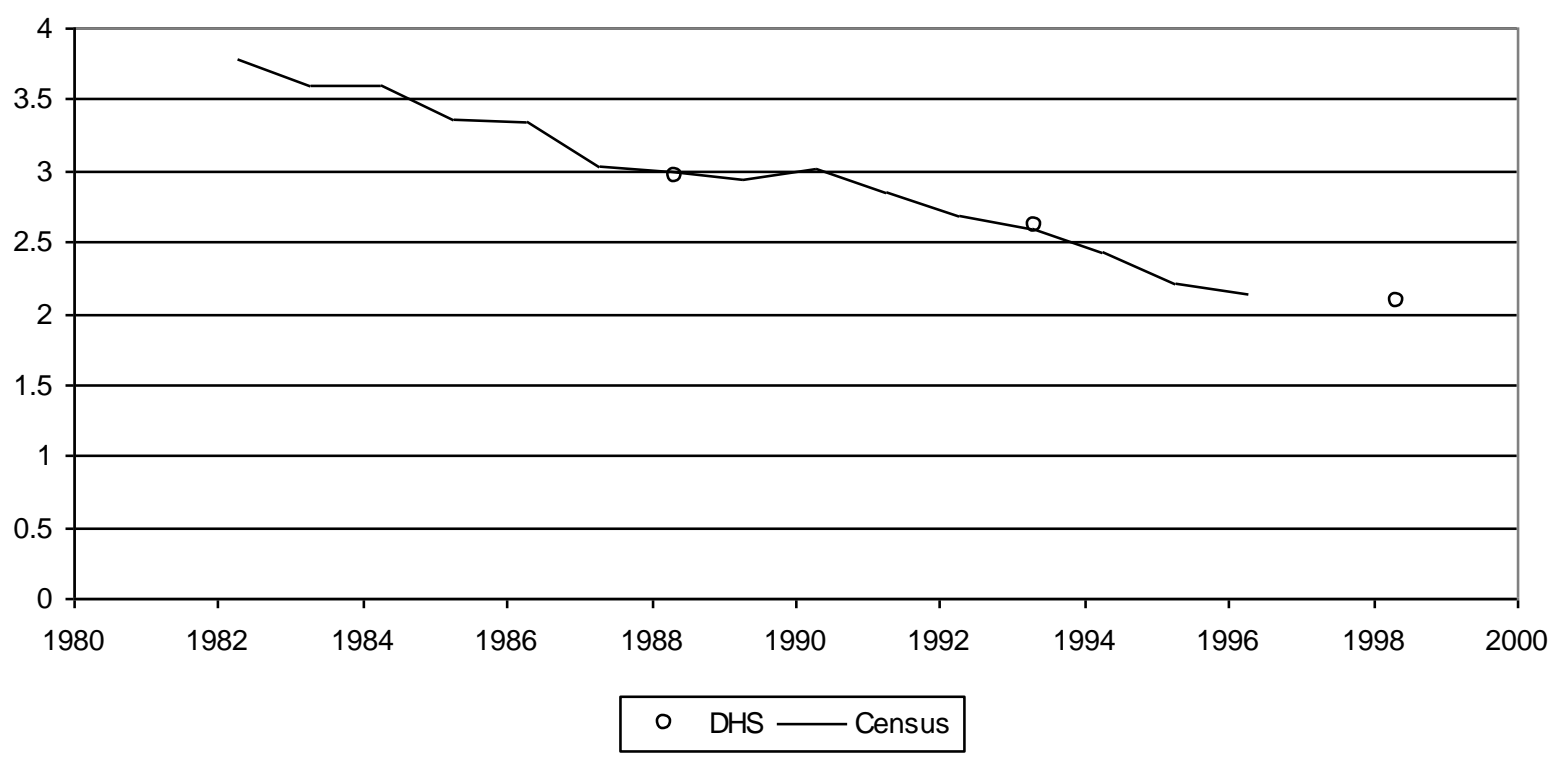

Figure 5 Cumulative fertility by age 35 of African South African women, 1982-1998 Source: Authors' calculations from 1998 DHS and 1996 Census data files 